Journal of Biotechnology and Strategic Health Research

\author{
Araştırma Makalesi / Research Article
}

http://dergipark.org.tr/tr/pub/bshr

\title{
Kistik Ekinokokkozis Şüpheli Hastaların İndirekt Hemaglutinasyon Yöntemiyle Değerlendirilmesi
}

\author{
Evaluation of Patients with Suspected Cystic Echinococcosis with \\ Indirect Hemagglutination Method
}

(iD) Mustafa Behçet, (iD Fatma Avcıoğlu

Tibbi Mikrobiyoloji Anabilim Dalı, Bolu Abant İzzet Baysal üniversitesi Tip Fakültesi, Bolu

ORCID ID: Mustafa Behcet 0000-0002-5976-6983, Fatma Avcioğlu 0000-0002-6011-7775

^Sorumlu Yazar / Corresponding Author: Dr. Öğr. Üyesi Mustafa Behcet, e-posta / e-mail: drmustafabehcet@gmail.com

Geliş Tarihi / Received : 11-02-2020 Kabul Tarihi / Accepted: 18-03-2020 Yayın Tarihi / Online Published: 30-04-2020

Atıf Gösterimi/How to Cite: Behçet M., Avcıŏlu F. Kistik Ekinokokkozis Şüpheli Hastaların İndirekt Hemaglutinasyon Yöntemiyle

Değerlendirilmesi, J Biotechnol and Strategic Health Res. 2020;4(1):26-31

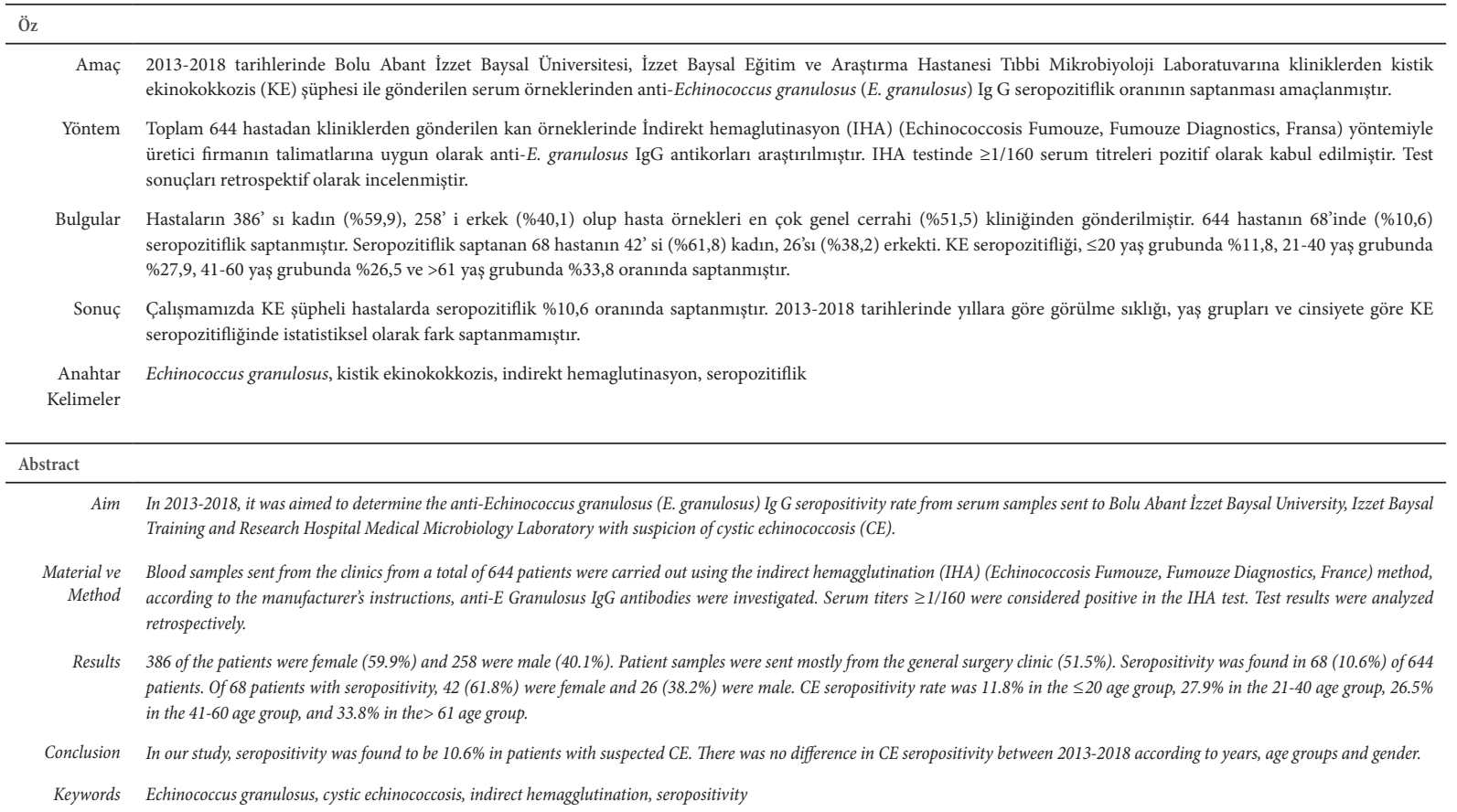




\section{GIIRIŞ}

Kistik ekinokokkozis (KE) bir sestod türü olan Echinococcus granulosus (E. granulosus)' un etken olduğu zoonotik bir enfeksiyon olup hidatik kist hastalığı olarak da bilinmektedir. ${ }^{2}$ Köpek ve kurt gibi etçil hayvanlar kesin konak olup koyun ve keçi gibi hayvanlar ise ara konaktır. Larvalar ara konakların iç organlarında, erişkin parazitler ise son konakların ince bağırsaklarında parazitlenirler. İnsanlar rastlantısal olarak Echinococcus türünün yumurtalarını yutarak ara konaklar haline gelebilirler. ${ }^{2-4}$

Gastrointestinal sistem yoluyla alınan yumurtadan çıkan embriyo (onkosfer), kancalarıyla bağırsak duvarına yapışır, daha sonra dolaşımına girer ve ilk önce karaciğere ulaşır. Bu nedenle karaciğer insanlarda en sık (\%50-70) görülen hastalık bölgesidir. Bunu akciğerler (\%20-30) ve daha az sıklıkta dalak, böbrekler, kalp, kemikler, merkezi sinir sistemi ve diğer organlar izler. ${ }^{1}$ Hastalık, çoğu kez yavaş büyüyen kistik bir kitle şeklindedir ve asemptomatiktir. Rüptüre olduğunda allerjik reaksiyon veya kistin süpüratif enfeksiyonu gibi komplikasyonlar meydana gelebilir. ${ }^{5}$

Radyolojik görüntüleme yöntemleri KE tanısı için önemlidir. Serolojik testlerin duyarlılı̆̆ı karaciğer kistlerinde $\% 88-96$, akciğer kistlerinde \%50-56, diğer organ kistlerinde \%25-26 olarak bildirilmiştir. En sık kullanılan serolojik testler; indirekt hemaglutinasyon (IHA), enzyme linked immunosorbent assay (ELISA), indirekt floresan antikor (IFA) ve spesifik IgG antikorlarını tespit eden immünoblotlama testleridir. İmmunoblotlama yöntemlerinden biri olan western blot testi doğrulama için kullanılırken ELISA ve IHA, KE tanısı için ilk basamak testlerdir. ${ }^{6}$ Dünya Sağlık Örgütü’ ne (WHO) göre, E. granulosus insidans oranlarının 100.000 kişide yılda 50’ ye kadar çıkmakta Güney Amerika, Doğu Avrupa, Rusya, Orta Doğu ve Çin' de endemik olarak görülmektedir. Ülkemizde hastalığın insidans1 ise 3,4/100,000 olarak bildirilmektedir., ${ }^{1,7}$

Bu çalışmada, 2013-2018 tarihlerinde Bolu Abant İzzet Baysal Üniversitesi, İzzet Baysal Eğitim ve Araştırma Has- tanesi Tibbi Mikrobiyoloji Laboratuvarına KE şüphesi ile kliniklerden gönderilen serum örneklerinde anti-E. granulosus IgG seropozitifliklerini belirlemek amaciyla IHA testi sonuçları retrospektif olarak araştırılmıştır.

\section{MATERYAL ve METOD}

Bu çalışma için Bolu Abant İzzet Baysal Üniversitesi klinik araştırmalar ve etik kurulundan (karar no: 2019/124) izin alınmıştır.

2013-2018 tarihleri arasında Tibbi Mikrobiyoloji Laboratuvarına KE şüphesi ile kliniklerden gönderilen toplam 644 hastaya ait kan örnekleri santrifüj edilerek serumları ayrılmıştır. IHA (Echinococcosis Fumouze, Fumouze Diagnostics, Fransa) yöntemiyle üretici firmanın test talimatlarına uygun olarak anti-E. granulosus IgG antikorları araştırılmıştır. Hastalara ait serum dilüsyonları U tabanlı mikroplaklarda yapılmıştır. Antijen içeren eritrosit eklenmiş kuyucuklarda 2 saatlik inkübasyondan sonra sonuçlar çökme şekline göre değerlendirilmiştir. IHA testinde $\geq 1 / 160$ serum titreleri pozitif olarak kabul edilmiştir. Test sonuçları retrospektif olarak incelenmiştir.

İstatistiksel değerlendirme için SPSS (21.0, SPSS Inc., ABD) programı kullanılmıştır. Yıllara göre, yaş gruplarına ve cinsiyete göre seropozitiflik oranlarının karşılaştırılmasında Ki Kare testi kullanılmış olup anlamlılık düzeyi $\mathrm{p}<0.05$ olarak alınmıştır.

\section{BULGULAR}

Yaşları 7-94 arasında değişen 386' sı kadın (\%59,9), 258' i erkek (\%40,1), toplam 644 hastadan oluşturulan çalışma grubunun yaş ortalaması $56,55 \pm 17,49$ olarak bulunmuştur.

Hasta kan örnekleri en çok Genel Cerrahi $(\% 51,5)$, Gastroenteroloji $(\% 17,6)$ ve Enfeksiyon Hastalıkları (\%13) kliniklerinden gönderilmiştir. Kan örneklerinin kliniklere göre dağılımı Çizim 1'de görülmektedir. 


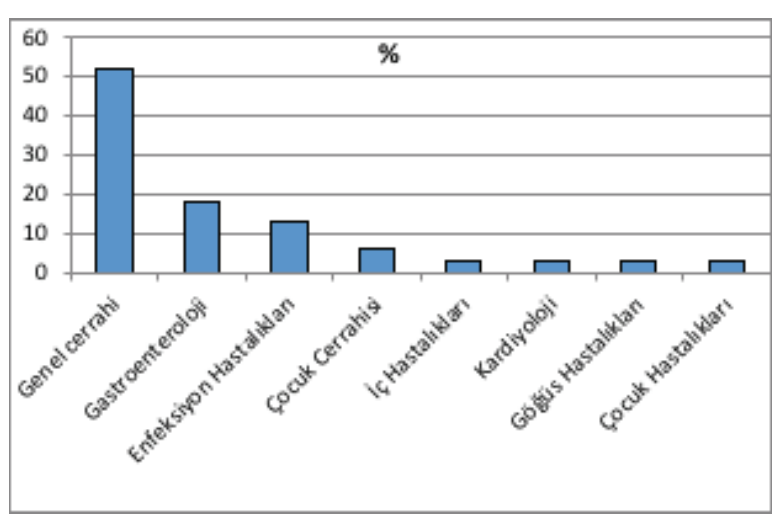

Çizim 1: Çalışmaya alınan hasta serum örneklerinin kliniklere göre dă̆ılımı

IHA testi ile seropozitiflik saptanan KE şüpheli 68 hastanın ön tanıdaki verilerine göre karaciğerde \%83.8, akciğerde $\% 8.8$, karaciğer+akciğerde \%4.4 ve karaciğer+böbrekte \%2.9 oranında kistik yapı olduğu saptanmıştır.

KE seropozitifliği 42’ si $(\% 61,8)$ kadın, 26’ sı $(\% 38,2)$ erkek toplam 68 hastada saptanmış olup istatistiksel olarak anlamlı fark bulunmamıştır ( $\mathrm{p}=0.638$ ). (Tablo 1).

\begin{tabular}{|l|rc|rr|rr|}
\hline \multicolumn{2}{|c|}{ Tablo 1. Cinsiyete göre KE seropozitiflik oranlar1 } \\
\hline & \multicolumn{2}{|c|}{$\mathbf{E}$} & \multicolumn{2}{|c|}{ K } & \multicolumn{2}{|c|}{ Toplam } \\
\hline & $\mathbf{n}$ & $\mathbf{( \% )}$ & $\mathbf{n}$ & $\mathbf{( \% )}$ & $\mathbf{n}$ & $\mathbf{( \% )}$ \\
\hline $1 / 160$ & 8 & $(42.1)$ & 11 & $(57.9)$ & 19 & $(100)$ \\
\hline$\geq 1 / 320$ & 18 & $(36.7)$ & 31 & $(63.3)$ & 49 & $(100)$ \\
\hline toplam & 26 & $(38.2)$ & 42 & $(61.8)$ & 68 & $(100)$ \\
\hline $\mathrm{p}=0.638$ & \multicolumn{7}{|c}{} \\
\hline
\end{tabular}

2013-2018 yılları arasında IHA testi sonuçlarına göre toplam 644 hastanın 19“ unda (\%3) 1/160, 49’ unda (\%7,6) $\geq 1 / 320$ titrede seropozitiflik olmak üzere toplam 68 (\%10,6) hastada seropozitiflik saptanmıştır. 2013-2018 yıllarında görülme sıklığı açısından KE seropozitifliğinde fark saptanmamıştır ( $\mathrm{p}=0.11)$ (Tablo 2).

\begin{tabular}{|c|c|c|c|c|c|c|c|}
\hline & 2013 & 2014 & 2015 & 2016 & 2017 & 2018 & toplam \\
\hline & $\begin{array}{c}n=94 \\
(\%)\end{array}$ & $\begin{array}{c}n=83 \\
(\%)\end{array}$ & $\begin{array}{c}n=70 \\
(\%)\end{array}$ & $\begin{array}{c}n=88 \\
(\%)\end{array}$ & $\begin{array}{c}\mathbf{n}=150 \\
(\%)\end{array}$ & $\begin{array}{c}\mathrm{n}=159 \\
(\%)\end{array}$ & $\begin{array}{c}\mathrm{n}=\mathbf{6 4 4} \\
(\%)\end{array}$ \\
\hline $1 / 160$ & $\begin{array}{c}- \\
(0)\end{array}$ & $\begin{array}{c}1 \\
(1.2)\end{array}$ & $\begin{array}{c}1 \\
(1.4)\end{array}$ & $\begin{array}{c}5 \\
(5.7)\end{array}$ & $\begin{array}{c}7 \\
(4.7)\end{array}$ & $\begin{array}{c}5 \\
(3.1)\end{array}$ & $\begin{array}{l}19 \\
(3)\end{array}$ \\
\hline$\geq 1 / 320$ & $\begin{array}{c}7 \\
(6.9)\end{array}$ & $\begin{array}{c}8 \\
(9.6)\end{array}$ & $\begin{array}{c}6 \\
(8.6)\end{array}$ & $\begin{array}{c}7 \\
(8)\end{array}$ & $\begin{array}{l}12 \\
(8)\end{array}$ & $\begin{array}{c}9 \\
(5.7)\end{array}$ & $\begin{array}{c}49 \\
(7.6)\end{array}$ \\
\hline toplam & $\begin{array}{c}7 \\
(6.9)\end{array}$ & $\begin{array}{c}9 \\
(10.8)\end{array}$ & $\begin{array}{c}7 \\
(10)\end{array}$ & $\begin{array}{c}12 \\
(13.6)\end{array}$ & $\begin{array}{c}19 \\
(12.7)\end{array}$ & $\begin{array}{c}14 \\
(8.8)\end{array}$ & $\begin{array}{c}68 \\
(10.6)\end{array}$ \\
\hline \multicolumn{8}{|l|}{$\mathrm{p}=0.11$} \\
\hline
\end{tabular}

$\leq 20$ yaş grubunda KE seropozitiflik oranı \%11,8, 20 yaş üzeri yaş gruplarında $\geq \% 26,5$ oranında saptanmış olup istatistiksel olarak fark bulunamamıştır ( $\mathrm{p}=0.98$ ) (Tablo 3).

\begin{tabular}{|c|c|c|c|c|}
\hline & $\leq 20$ & $21-40$ & $41-60$ & $>61$ \\
\hline & n $\quad$ (\%) & n $\quad(\%)$ & n $\quad$ (\%) & n $\quad(\%)$ \\
\hline $1 / 160$ & $2(10.5)$ & $5 \quad(26.3)$ & $5 \quad(26.3)$ & $7 \quad(36.8)$ \\
\hline$\geq 1 / 320$ & $6(12.2)$ & $14(28.6)$ & $13(26.5)$ & $16(32.7)$ \\
\hline toplam & $8 \quad(11.8)$ & 19 (27.9) & $18(26.5)$ & $23(33.8)$ \\
\hline \multicolumn{5}{|l|}{$\mathrm{p}=0.988$} \\
\hline
\end{tabular}

\section{TARTIŞMA}

$\mathrm{KE}$, dünyada en yaygın görülen paraziter hastalıklardan birisi olup insanlar için önemli bir sağlık sorunu ve ülkeler için ise ekonomik bir sorun olma özelliğini devam ettirmektedir. ${ }^{8}$ Özellikle hayvancılığın yaygın olduğu ülkelerde insidansı yüksek olup uzun yıllar asemptomatik seyredebilen bir hastalıktır. ${ }^{9}$ Kist hidatik hastalığının tanısında belirgin klinik bulguların olmaması nedeniyle hastalığın tanısında klinik bulgulardan çok laboratuvar bulgularından yararlanılmaktadır. ${ }^{10}$ Yapısı bozulmuş kistlerde ve post operatif hastaların takibinde USG, MR ve BT gibi radyodiagnostik tanı yöntemleri yetersiz kalmakta; bu gibi durumlarda hem tanının doğrulanması hem de post operatif nükslerin takibinde oldukça yararlı olan serolojik tanı yöntemleri kullanılmaktadır. ${ }^{6}$ IHA testinin rutin laboratuvarda kısa zamanda sonuç vermesi, kolay uygulanabilir ve düşük maliyetli olasından dolayı KE’ nin primer tanısında güvenle kullanılabileceği, ayrıca testin duyarlılık ve özgüllüğünün diğer serolojik testlere kıyasla daha yüksek oldu- 
gu bildirilmiştir. ${ }^{11}$ Serolojik testler sadece hasta olgularını saptamakla kalmayıp; asemptomik kist taşıyıcılarını, toplumdaki yaygınlığını ve kontrol programlarının etkinliğini saptamak amacıyla da kullanılmaktadır. ${ }^{8}$

Çalışmamızla benzer şekilde KE öntanısıyla laboratuvara gönderilen örneklerden retrospektif olarak yapılan bazı çalışmalarda $\geq 1 / 160$ seropozitiflik oranı $\% 12,7-25,1$ arasında bildirilmiştir. ${ }^{11,12}$ Balıkesir' de yapılan bir çalışmada $\geq 1 / 320$ titrede pozitiflik oranı $\% 19,8$ olarak saptanmıştır. ${ }^{13}$ Çalışmamızda saptadığımız $\geq 1 / 160$ titrede (\%10.6) ve $\geq 1 / 320$ titrede $(\% 7,6)$ seropozitiflik oranları bu çalışmalara göre daha düşük oranlardadır. Erzurum'da yapılan bir çalışmada seropozitiflik oranı \%9,5 olarak bildirilmiş olup çalışmamızla benzer orandadır. ${ }^{3}$

Ülkemizde yapılan bazı seroprevalans çalışmalarında Kayseri' de ELİSA ve IFA testi ile seropozitiflik oranı \%2.7, Aydin' da ultrasonografi ile \%0,47, ELISA ile \%11,48 ve IHA ile $\% 13,39$ oranında saptanmıştır. ${ }^{14,15} \mathrm{Bu}$ çalışmalardan da anlaşılacağı üzere hastane kayıtlarına dayalı geriye dönük çalışmalar ile prevalans çalışmaları arasında farklar olduğu görülmektedir. Hastane kayıtlarına göre geriye dönük olarak elde edilen verilerde seropozitiflik oranlarının yüksek olması, KE öntanılı hasta grubundan kaynaklanmaktadır. Çeşitli çalışmalarda hastalığın cinsiyet ile ilişkisi incelenmiştir. KE’nin kadınlarda erkeklere oranla daha sık görüldüğü bildirilmektedir. ${ }^{14}$ Eşgin ve arkadaşları ${ }^{8} \mathrm{KE}$ seropozitifliğini kadınlarda \%81.44 olarak saptamışlardır. Yapılan birçok çalışmada KE seropozitiflik oranı (\%55,9-60,6) çalışmamızla $(\% 61,8)$ uyumlu olarak kadınlarda daha sık görülmekle birlikte istatistiksel olarak anlamlı bulunmamıştır. ${ }^{3,10,12}$

KE, bütün yaş gruplarında görülür. Bazı endemik alanlarda hastane vakalarının çoğunun 21- 40 yaş grubunda olduğu bildirilmiştir. ${ }^{16}$ Delibaş ve arkadaşları ${ }^{9}$ KE tanısı alan hastaların \%72'sinin 20-60 yaş grubunda, Çitil ve ar$\operatorname{kadaşlar1}^{17} \% 70$ ' inin 20 yaş üstünde, Kılıç ve arkadaşları ${ }^{12}$ en yüksek pozitifliğin 41-60 yaş grubunda, Güreser ve ar- kadaşlar1 ${ }^{11}$ ise $\% 70$ ' inin 40 yaş üstü olduğunu bildirmişlerdir. Çalışmamızda da 20 yaş üzeri seropozitiflik oranı (>20 yaş üzeri yaş grupları toplam oranı $\% 88,2$ ) bu çalışmalarla uyumlu olarak daha fazla görülmüştür. Ancak yaş grupları arasında istatistiksel olarak fark bulunamamıştır $(\leq 20$ yaş grubunda \%11,8, 21-40 yaş grubunda \%27,9, 41-60 yaş grubunda $\% 26,5$ ve $>61$ yaş grubunda $\% 33,8)$. Bu sonuçlar, hastalığın zamanla ve yavaş bir şekilde ortaya çıktığını desteklemektedir. ${ }^{9}$

Güreser ve arkadaşlarının ${ }^{11}$ yapmış oldukları çalışmada serum örneklerinin en sı Genel Cerrahi (\%43,8), Gastroenteroloji $(\% 21,9)$ ve Enfeksiyon Hastalıkları $(\% 21,9)$ kliniklerinden yine Şafak ve arkadaşlarının ${ }^{13}$ yapmış odukları çalışmada serum örneklerinin en sık Genel Cerrahi $(\% 48,3)$, İç Hastalıkları-Gastroenteroloji $(\% 19,6)$ ve Enfeksiyon Hastalıkları (\%14,5) kliniklerinden gönderildiği belirtilmiştir. Çalışmamızda da hasta serum örnekleri bu çalışmalara benzer şekilde en sık Genel Cerrahi (\%51,5), Gastroenteroloji $(\% 17,6)$ ve Enfeksiyon Hastalıkları (\%13) kliniklerinden gönderilmiştir.

KE ile ilgili ülkemizde yapılan bazı çalışmalarda en sık organ tutulumu karaciğer (\%68.18-89) olarak bildirilmiştir $^{8,9,17}$. KE' de organ tutulumu olarak Çitil ve ark. ${ }^{17}$ ikinci sıklıkta akciğer (\%11), Eşgin ve ark. ${ }^{8}$ ikinci sıklıkta karaciğer+akciğer (\%36.63), üçüncü sıklıkta akciğer (\%13.63), Delibaş ve ark. ${ }^{9}$ ikinci sıklıkta karaciğer+akciğer (\%16.2) ve üçüncü sıklıkta(\%11.2) akciğer olarak bildirilmiştir. Çalışmamızda IHA testi ile seropozitiflik saptanan KE şüpheli hastaların ön tanıdaki verilerine göre bu çalışmalarla uyumlu olarak en sık karaciğerde (\%83.8) oranında tutulum saptanırken ikinci sırada akciğerde (\%8.8) ve üçüncü sırada karaciğer+akciğerde (\%4.4) organ tutulumu saptanmıştır.

Sonuç olarak 2013-2018 tarihlerinde yıllara göre görülme sıklığı açısından KE seropozitifliğinde fark görülmemiştir. KE, 20 yaş üzeri yaş gruplarında ve kadınlarda sayısal olarak daha fazla görülmesine rağmen istatistiksel olarak fark 
J Biotechnol and Strategic Health Res. 2020;4(1):26-31

saptanmamıştır. Çalışmamızda KE ön tanılı hastalarda seropozitiflik oranı, benzer çalışmalarla kıyaslandığında daha az oranda saptanmış olmakla birlikte hedef, koruma ve kontrol önlemleriyle hastalığın eradikasyonu olmalıdır.

\section{Çıkar Çatışması Beyanı}

Yazarların herhangi bir çıkar ilişkisi yoktur.

\section{Finansal Destek}

Çalı̧̧maya maddi destek veren kişi/kuruluş yoktur. 
J Biotechnol and Strategic Health Res. 2020;4(1):26-31

BEHÇET, AVCIOĞLU, Kistik Ekinokokkozis'in İHA yöntemiyle değerlendirilmesi

\section{Kaynaklar}

1. Bhutani N, Kajal P. Hepatic echinococcosis: A review. Ann Med Surg. 2018; 36: 99-105.

2. Shiferaw F, Bekele W, Giro B, et al. Epidemiology and economic importance of hydatidosis in domestic animal and human in Ethiopia- A Review. J Vet Sci Technol. 2018; 9(6): 563.

3. Yllmaz A, Uslu H, Aktaş F. 2009-2013 yılları arasında Erzurum Bölge Hastanesindeki kistik ekinokokkozis șüpheli hastaların indirekt hemaglütinasyon (IHA) metoduyla değerlendirilmesi. Gümüşhane Üniversitesi Să̆ltk Bilimleri Dergisi. 2016; 5(1): 23-32.

4. Așcı Toraman Z, Aslan R, Arı N, et al. 2011 yllinda kistik ekinokokkozis şüphesi ile bașvuran hastalarda IHA sonuçları. F.Ü.Să̆.Bil.Tip Derg. 2014; 28 (2): 55-58.

5. Kayataş S, Kurt D, Arınkan S, et al. Over tümörünü taklid eden primer pelvik hidatik kist: olgu sunumu. Bozok Tip Derg. 2014; 4(1): 88-91.

6. Güreser AS, Duman GG, Sarzhanov F, et al. Western blot assay of anti-Echinococcus granulosus antibody positive serum samples by indirect haemagglutination method. Turk Hij Den Biyol Derg. 2019; 76(2): 195-202.

7. Çobanoğlu U, Sayır F, Mergan D. Kist hidatik hastalarıyla aynı yașam alanını paylaşan bireylerde radyolojik ve serolojik tarama sonuçları. Turkiye Parazitol Derg. 2012; 36(2): 65-70.

8. Essgin M, Aktaș M, Coșkun Ș. İndirekt hemaglütinasyon testi (IHA) yöntemi ile kistik ekinokkokoz şüpheli hastaların serumlarında antikor varliğını Araștırlmass. Turkiye Parazitol Derg. 2007; 31: 283-287.

9. Delibaş SB, Özkoç S, Șahin S, et al. Dokuz Eylül Üniversitesi Tip Fakültesi Parazitoloji Anabilim Dalı Seroloji Laboratuvari' na kistik ekinokokkozis șüphesiyle başvuran hastaların değerlendirilmesi. Türkiye Parazitol Derg. 2006; 30: 279-281.
10. Akgün S, Sayıner H, Karslgil T. Kistik ekinokokoz' un serolojik tanısında indirekt hemaglütinasyon, indirekt floresan antikor ve enzim immuno assay testlerinin etkinliğinin değerlendirilmesi. J Contemp Med. 2018; 8(1): 14-19.

11. Güreser AS, Özcan O, Özünel L, et al. Corum' da kistik ekinokokkoz ön tanısı ile bașvuran hastaların radyolojik, biyokimyasal ve serolojik analizlerinin değerlendirilmesi. Mikrobiyol Bül. 2015; 49(2): 231-239.

12. Killç S, Babür C, Özkan AT. Kist hidatik ön tanıl olgularda indirek hemaglutinasyon ve ELISA yöntemleri ile alınan sonuçların karşılaştırılması. Mikrobiyol Bül. 2007; 41: 571-577.

13. Safak, B. Balıkesir Atatürk Devlet Hastanesi 2011-2013 yılları arası kistik ekinokokkozis serolojisi sonuçları. Kocatepe Tip Dergisi. 2015; 16(4): 265-268.

14. Ertabaklar H, Dayanır Y, Ertuğ S. Aydın ilinin farklı bölgelerinde ultrason ve serolojik yöntemlerle kistik ekinokokkoz araștırılması ve eğitim çalıșmaları. Turkiye Parazitol Derg. 2012; 36: 142-146

15. Yazar S, Yaman O, Çetinkaya F, et al. Cystic echinococcosis in central Anatolia, Turkey. Saudi Med J. 2006; 27: 205-209.

16. Özgür T, Kaya ÖA, Hakverdi S, et al. Ekinokokkozis olgularmnn histopatolojik yönden retrospektif olarak değerlendirilmesi. Dicle Tip Dergisi 2013; 40(4): 641-644.

17. Citil BE, Tunçoğlu E, Erbil ÖF, Değirmenci, Özenoğlu A, Sert Het al. Adlyaman’ da kistik ekinokokkozis ön tanıl hastaların indirekt hemaglütinasyon (IHA) yöntemi ile değerlendi rilmesi. Van Tip Dergisi. 2015; 22(4): 220-224. 